\title{
The Regulation of Military Insubordination in Indonesia
}

\author{
Adis Nevi Yuliani ${ }^{1} \quad$ Marwati Riza $^{2} \quad$ Andi Muhammad Sofyan ${ }^{2} \quad$ Muhadar $^{2}$ \\ 1.Doctoral Student, Faculty of Law, Hasanuddin University, Indonesia \\ 2 .Professor, Faculty of Law, Hasanuddin University, Indonesia
}

\begin{abstract}
The insubordination carried out by the military was an act of disgrace and violated the Sapta Marga and the Soldier's Oath and the applicable law. Legal arrangements for insubordination are regulated in the Military Criminal Code and Law No. 25 of 2014. Law enforcement against insubordination measures aims to safeguard the dignity of the commander or leadership and is an effort to foster the obedience of subordinates to the command in carrying out military duties.
\end{abstract}

Keywords: Insubordination, Military Crime, Military Command

DOI: $10.7176 / \mathrm{JLPG} / 101-08$

Publication date:September $30^{\text {th }} 2020$

\section{A. Introduction}

Indonesian National Army ${ }^{1}$ (TNI) is formed based on Article 30 paragraph (2) of the 1945 Constitution which states that national defense and security efforts are carried out through the defense and security system of the total people by the Indonesian National Army and the Indonesian National Police. Furthermore in paragraph (3) the article contains that the Indonesian National Army consists of the Army, Navy and Air Force as state instruments. ${ }^{2}$ The Indonesian National Army (TNI) as a means of defense of the Unitary State of the Republic of Indonesia, is tasked with implementing state defense policies to uphold state sovereignty, maintain territorial integrity, and protect the safety of the nation, carry out military operations for war and military operations other than war, and participate actively in tasks regional and international peacekeeping. ${ }^{3}$ TNI is established and developed professionally in accordance with the political interests of the country, referring to the values and principles of democracy, civil supremacy, human rights, national law, and international law that have been ratified by Indonesia. ${ }^{4}$

In the MPR Decree No. VI of 2000 and MPR Decree No. VII of 2000 gave birth to Reform in the field of National Defense. ${ }^{5}$ Law No. 3 of 2002 replacing Law No. 20 of 1982 is a form of the implementation of Reform in the defense sector, Law No. 20 of 1982 is no longer in line with the demands of reform. Law No. 3 of 2002 in addition to regulating the restructuring of the state defense authority, it also made a number of fundamental changes in the implementation of state defense in the future to support national interests in accordance with the ideals of reform as well as for national goals.

The birth of Law No. 3 of 2002 regulates the powers, duties and responsibilities of the Ministry of Defense, as well as the roles, duties and responsibilities of the Indonesian National Armed Forces, the powers, duties and responsibilities of the TNI Commander. In the framework of reform within the TNI institution, constructive steps are taken in line with the development of a democratic government and society. This was done as a form of commitment in the form of internal reform of the TNI. The reform of the TNI institution aims to organize its functions and duties as mandated in Law No. 3 of 2002. Internal reform is a necessity for the TNI to create a professional TNI institution and is implemented gradually and continuously.

The international community, the military like the TNI, is recognized as having the quality of organization,

\footnotetext{
${ }^{1}$ The struggle for independence then began when Japan formed a people's army which was named PETA or Defenders of the Homeland in the period 1942-1945 when it occupied the Indonesian nation. During its development, PETA served to assist Japan in the war in Greater East Asia which later became the forerunner to the formation of the Indonesian National Army (TNI). PETA members consist of 66 battalions spread across Java, Bali and Sumatra. Several PETA members who later became Indonesian revolutionary heroes, namely Great Generals Soedirman, Soeharto, Achmad Yani and Supriyadi. The establishment of Indonesia as an independent nation was followed by the dissolution of PETA. The Indonesian government at that time was led by the founding father Soekarno and Muhammad Hatta along with members of BPUPKI and PPKI at that time then designed the basis of the State as the highest Constitution which became the foundation of the nation's philosophy in living the sustainability of the nation and as a homeland. The Indonesian government then formed an official body called the People's Security Agency (BKR) which would guard the country's sovereignty, what is interesting is that the recruitment of former PETA members was an integral part of the struggle for Indonesian independence. On 5 October 1945 the BKR changed its name to the People's Security Army (BKR) which was later changed again to the Indonesian Army (TRI). It was only on June 3, 1947, that President Soekarno inaugurated the new name for this defense institution to become the Indonesian National Army (TNI).

${ }^{2}$ Sa'diyah, Nur Khalimatus, and Ria Tri Vinata. (2016). Rekonstruksi Pembentukan National Cyber Defense sebagai Upaya Mempertahankan Kedaulatan Negara. Perspektif: Kajian Masalah Hukum dan Pembangunan, Vol. 21.3: 168-187.

${ }^{3}$ Efendy, Rifki. (2014). Kedudukan dan kewenangan Tentara Nasional Indonesia dalam pemberantasan terorisme di indonesia. Lex Crimen, Vol 3.1.

${ }^{4}$ Elucidation of Law No. 34 of 2004

${ }^{5}$ Kesumo, E. (2011). Proses Peradilan Terhadap Prajurit Tni Yang Melakukan Tindak Pidana Umum. Doctoral Dissertation, Universitas Airlangga.
} 
although in the country's economic situation, however difficult it is, the characteristics of the quality of the organization remain prominent, like Indonesia today. The TNI remains cohesive and able to maintain its hierarchy. The TNI is a state instrument that has a solid goal, namely to maintain the integrity of the nation and state. As an institution, the TNI is formed and is under the orders of the state leadership and this fact is regulated in the 1945 Constitution Article 10. The TNI is formed to carry out its special tasks, namely state defense while remaining united with the power of the people in the " Hankamrata" system. ${ }^{1}$ Hankamrata stands for Universal People's Security Defense which is a universal defense system, which involves all citizens, territories and other national resources, and is prepared early by the government and is carried out in a total, integrated, directed, sustainable and sustainable manner to uphold sovereignty. state, maintain the territorial integrity of the Unitary State of the Republic of Indonesia and protect the safety of the entire nation from any threats. ${ }^{2}$

In carrying out their duties, TNI soldiers are required to have high discipline, great responsibility, and good morals in order to serve the nation and state. For a soldier, loyalty to duty is everything. During his tenure, TNI soldiers were implanted with life guidelines used to carry out tasks such as the Soldier's Oath, Sapta Marga, Eight Compulsory TNI and Tri Darma Eka Karma (Tridek), as well as other regulations that apply to TNI soldiers. The guidelines are expected to be a filter for the life of TNI soldiers to be devoted to God Almighty, to be chivalrous, honest and responsible for their actions. An attitude that must be carried out by every soldier from the lowest position to the highest position.

The most important thing in the life of a soldier is discipline, without military discipline like an armed horde. This is in accordance with the disciplinary provisions for TNI soldiers as regulated in Law No. 26 of 1997 which has been renewed by Law no. 25 of 2014 and Decree of the TNI Commander Number: Kep / 22 / VIII / 2005 dated 10 August 2005. The two regulations stipulate how TNI soldiers must behave in a disciplined manner in order to carry out their official duties.

In reality, the implementation of the TNI's main duties includes various violations or criminal acts committed by soldiers, both violations of criminal law and violations of military discipline law. In practice, it turns out that as ordinary people, the TNI sometimes forgets or negligent, ${ }^{3}$ then it can be said that there are still frequently encountered TNI soldiers who commit disgraceful acts and even violate the Sapta Marga and the Soldier's Oath and the applicable law. ${ }^{4}$

In this context, there are two cases of violations commonly committed by TNI soldiers in the form of Disersion ${ }^{5}$ or escaping from their assigned duties or the absence of a military officer without the direct commander's permission, and Insubordination ${ }^{6}$ or fighting the commander committed by soldiers or members of the TNI, are cases which is usually found within the scope of TNI members. The legal basis can be seen in the provisions of the Laws on Military Criminal Law, namely Wetboek Van Militair Strafrecht (stbl. 1934 Nr. 167 jo Law No. 39 of 1947) on the Military Criminal Code (KUHPM). ${ }^{7}$

The violation which is quite a lot committed by TNI soldiers is the crime of disobeying orders/insubordination. ${ }^{8}$ Within the TNI, disobedience is a violation that cannot exist and is considered a criminal act so that it is regulated in Articles 103 - 109 of the Military Criminal Code.

Pure military crimes are prohibited / mandatory acts which in principle can only be violated by a military person, because of a special nature or because a military interest requires that such action be determined as a criminal offense or what is also called "military crime". ${ }^{9}$ One example of a pure military crime is "insubordination"

\footnotetext{
${ }^{1}$ Tommy Sihotang, (2009). Penelaahan Hukum Militer untuk Memperkuat Ketahanan Nasional dan Perlindungan Hak Asasi Manusia, Sekretariat Jenderal Departemen Pertahanan Biro Hukum, p..22

${ }^{2}$ https://id.wikipedia.org/wiki/HANKAMRATA, Accessed on 10 March 2019

${ }^{3}$ Randy, Yavisparta, and Mahendra Putra. (2015). Asas Unus Testis Nullus Testis Sebagai Dasar Terdakwa Mengajukan Permohonan Banding Ke Pengadilan Militer Utama." Verstek, Vol.3.2.

${ }^{4}$ Putra, Ivandra Oktarino. (2019). Pertimbangan Mahkamah Agung Mengabulkan Permohonan Kasasi Oditur Militer Terhadap Putusan Bebas Dalam Perkara Tindak Pidana Pencurian dalam Keadaan Memberatkan. Verstek, Vol.7.1. See also, Rudiansyah, Rudiansyah. (2018). Tinjauan Yuridis Terhadap Pelanggaran Prajurit Militer Di Lingkunagn Korem 101 Antasari Banjarmasin Menurut Undangundang Nomor 25 Tahun 2014 Tentang Hukum Disiplin Militer. Repository Universitas Islam Kalimantan..

${ }^{5}$ Amu, Robi. (2012). Kajian Hukum Pidana Militer Indonesia Terhadap Tindak Pidana Desersi. Jurnal Legalitas, Vol 5.01. See Also Cahyadi, Cokorda Bagus Aries. (2017). Kajian Hukum Militer Terhadap Tni Yang Melakukan Tindak Pidana Desersi. Jurnal Kertha Wicaksana, Vol. 1.3. See Also Hendrik, Jhoni. (2019). Penanggulangan Tindak Pidana Desersi Terhadap Prajurit Tni Al. Unes Journal Of Swara Justisia, Vol. 3.1: 78-91.

${ }^{6}$ Haris, O. K., \& Hidayat, S. (2019). Pertanggungjawaban Pidana Anggota Militer Yang Melakukan Tindak Pidana Insubordinasi Dengan Tindakan Nyata Dalam Peradilan Militer. Halu Oleo Legal Research, 1(1), 99-110. See Also, Bukhari, A., \& Abudan, M. (2019). Penegakan Hukum Tindak Pidana Insubordinasi Dalam Militer (Studi Kasus Putusan Pm Nomor: 94-K/Pm. Iii-12/Ad/Vi/2015). Jurnal Hukum Adigama, 2(1), 74-97. See Also, Chandra, R. (2020). Penyelesaian Kasus Hukum Di Lingkungan Pengadilan Militer Dalam Perkara Tindak Pidana Penipuan Yang Dilakukan Oleh Anggota Tni. Pamulang Law Review, 1(2), 75-86.

7 Soebagijo, H. (2011). Kebijakan Hukum Pidana Dalam Pemeriksaan Terhadap Prajurit Tni Pelaku Tindak Pidana Umum. Law Reform, 7(1), 21-49. See Also. Sirait, B., \& Sahari, A. (2014). Peranan Polisi Militer Angkatan Udara Di Dalam Penyidikan Kasus Narkoba Dalam Wilayah Hukum Lanud Soewondo (Medan). Jurnal Mercatoria, 7(1), 30-45.

${ }^{8}$ Sinaga, N. S. Pembangkangan Militer (Melanggar Pasal 103 Kuhpm) Di Lingkungan Tni AD Di Wilayah Yonif 643/Wanara Sakti Kompi B Ditinjau Dari Sudut Kriminologi. Jurnal Hukum Prodi Ilmu Hukum Fakultas Hukum Universitas Tanjungpura, 3(3).

${ }^{9}$ Putra, T. D. (2013). Penerapan Hukum Militer Terhadap Anggota TNI Yang Melakukan Tindak Pidana Desersi. Lex Crimen, 2(2). See Also,
} 
or what is more generally said to be disobedience to a commander's order. Insubordination is regulated in the Military Criminal Code in Chapter IV of Criminal Acts against Service as specified in Articles 103-109 of the Military Criminal Code.

From the results of the investigation of these cases, the author found various decisions against TNI soldiers who committed insubordination crimes. Judgments by the courts on violating soldiers tend to be light, even though the crime of insubordination is a serious offense because it can affect the military defense system in Indonesia. This is quite reasonable because insubordination activities can pollute the existing code of ethics in the military environment, namely the Sapta Marga and the Soldier's Oath, which essentially require soldiers to be disciplined and obey the orders of their commanders. The description of these cases of insubordination is the duty of every commander in each force, because the handling of those involved in the case of insubordination is of course very different from cases of violations or other criminal acts. In practice, those who commit the insubordination violation, after being given punishment and still acceptable back into their units, are not fired (expelled from the TNI), so their guidance must be more specific and extra careful, since the mental condition of soldiers requires a lot of attention from the commanders in every military field.

In connection with this, the training process that is being carried out must be able to be fixed and improved, not only to fulfill the interests of law enforcement and military discipline, but also for the interests of TNI members themselves, so that through this guidance, they will become members of the TNI who are aware and obedient to Sapta Marga, the Soldier's Oath, the law and avoid any despicable acts that are prohibited by legal norms and provisions in force in the TNI.

For this reason, this article will discuss how the legal arrangements for insubordinate crimes committed by the military and form the legal formulation for insubordination crimes as a reform in military law in Indonesia. This article uses a normative juridical review ${ }^{1}$ namely by focusing its study by viewing law as a complete system, a set of legal principles and legal norms. The research was conducted by abstracting concepts, principles, doctrines, theories, legal norms, and legal rules (written or unwritten). ${ }^{2}$ Then an analysis is carried out to produce a conclusion on solving the problem related to the crime of insubordination.

\section{B. Analysis And Discussion}

\section{Legal Arrangements for Insubordination In the Military Legal Order}

Equality before the law is the main principle in the enforcement of legal provisions for anyone, both civilians, including TNI soldiers. This principle is of course relevant to the Indonesian constitution in Article 27 paragraph (1) that all citizens have the same position in law and government and are obliged to uphold the law and government without exception. Military life that is different from civil society certainly requires more specific provisions because they have different duties and functions from society in general, even though TNI soldiers are also part of the Indonesian people.

The 1945 Constitution as a statutory norm (staatsfundamentalnorm), to be precise in Article 30 paragraph (3) states that the Indonesian National Army consists of the Army, Navy and Air Force as state instruments in charge of protecting, protecting, serving the community and enforcing the law. This has become the basis for the existence of the TNI in Indonesia as a bastion of national defense.

TNI soldiers in carrying out their roles, duties and functions are always guided by the Sapta marga which contains:

1. We are citizens of the unitary state of the Republic of Indonesia which teaches Pancasila.

2. We are Indonesian patriots, supporters and defenders of state ideology who are responsible and do not know to give up.

3. We are Indonesian knights, who fear the Almighty God, and defend honesty, truth and justice.

4. We are soldiers of the Indonesian National Army, are the Bhayangkari of the Indonesian State and Nation.

5. We are soldiers of the Indonesian National Army, uphold discipline, obey and obey the leadership and uphold the attitude and honor of soldiers.

6. We soldiers of the Indonesian National Army prioritize heroism in carrying out our duties, and are always ready to serve the state and nation.

7. We soldiers of the Indonesian National Army are loyal and keep our promises and Oaths of soldiers.

Sapta Marga is a tribute that is given to soldiers as life. As stated in the provisions of the TNI education master guideline at number five, which requires soldiers to be disciplined and firm in their stance and obey superiors inside and outside the unit, and remain respectful in maintaining their attitude. The sixth figure requires soldiers to prioritize entrepreneurship while on duty. The soldier's oath is related to the charge of obedience to the previous figures. In addition, a soldier is also obliged to obey any existing regulations within the TNI, including

Tiku, I. A. (2020). Kajian Yuridis Terhadap Tindak Pidana Korupsi Yang Di Lakukan Oleh Pejabat Tni. Lex Crimen, 9(2).

${ }^{1}$ Soerjono Soekanto, (1986), Pengantar Penelitian Hukum, Jakarta: UI Press, p.10

${ }^{2}$ Achmad Ali, (2002), Menguak Tabir Hukum (Suatu Kajian Filosofis dan Sosiologis, Jakarta : Tokoh Gunung Agung, p. 319 
obedience to his superiors as the soul of the clan and the soldier's oath. ${ }^{1}$

Sapta Marga of TNI soldiers is an essential guide in maintaining loyalty to the Republic of Indonesia. Loyalty, which means loyalty that does not come from one party, also cannot be realized without trust.

The commander will not get the loyalty of his subordinates when: ${ }^{2}$

1. Not trusted and cannot trust their subordinates;

2. Does not love his subordinates and units;

3. Not dedicated and not patriotic.

The reasons mentioned above also apply to the opposite, the loyalty of the subordinates of the commander. This had a serious impact when disputes occurred between subordinates and commanders.

In addition to the sapta marga, there is also a Soldier's Oath to form the personality pattern of TNI soldiers, the TNI soldier's oath in question is:

"By Allah / Dei Tuhan / Om Atah Parama Wisesa / By Sang Hyang Adhi Buddha, I swear / promise:"

1. That I will be loyal to the unitary state of the Republic of Indonesia which is based on Pancasila and the 1945 Constitution of the Republic of Indonesia;

2. That I will obey the law and uphold the discipline of soldiering;

3. That I will obey the commander by not contradicting orders or decisions;

4. That I will carry out all obligations with a full sense of responsibility to the army and the Republic of Indonesia.

In point 5, the Sapta Marga soldiers declared that we are soldiers of the Indonesian National Army, uphold discipline, obey and obey the leadership and uphold the attitude and honor of soldiers and also the soldier's oath in point 2 then becomes the basis for regulations regarding the crime of insubordination. Insubordination is a criminal offense against a commando order which is very inappropriate to do because it deviates from the sapta marga and the soldier's oath.

In Indonesia, TNI soldiers are subject to civilian regulations, namely Article 459 - Article 461 of the Criminal Code (KUHP), while Article 106 - Article 109 of the Military Criminal Code (KUHPM).

In the provisions of Article 459 of the Criminal Code, it describes:

1) Passengers on an Indonesian ship who were on board an attack on the captain or crew on the ship or in carrying out their work carried out an attack on a person of higher rank or against that person with violence or threats of violence or deliberately depriving them of their freedom, shall be punished for insubordination with a maximum imprisonment of two years and eight months.

2) Guilt is punished:

a. A maximum imprisonment of four years, if the crime or the act accompanying said crime caused injury;

b. A maximum imprisonment of eight years and six months if the act causes serious injury to a person;

c. The maximum imprisonment of twelve years, if said act causes a person to die.

The use of the word disobedient in the article above is synonymous with insubordination, which means that there are attitudes and actions taken by subordinates to deviant superiors. This article also only regulates actions against ship captains so that they cannot be used to ensnare actors outside the elements of the article. However, it is the rationale for the formation of more specific regulations regarding the crime of insubordination within the military. More specific legal arrangements regarding military crimes, including crimes of insubordination, then become guidelines that TNI soldiers must obey. Insubordination is then regulated in Articles 106-109 of the Military Criminal Code

According to Article 106 of the Military Criminal Code it is stated, among others:

1) The military, who deliberately attacks a commander, opposes him by force or threat of violence, deprives him of his freedom to act, or forces him by force and threats of violence to carry out or neglect an official job, is threatened because of insubordination with real action with a maximum imprisonment. nine years.

2) If the act results in injury, the offender shall be punished by a maximum imprisonment of ten years.

3) If said act results in death, the offender shall be punished by a maximum imprisonment of twelve years.

Article 107, this article contains:

1) Insubordination by real action, which is planned in advance with a maximum penalty of ten years

2) If said act results in injury, the offender shall be punished by a maximum imprisonment of twelve years

3) If said act results in death, the offender shall be punished by a maximum imprisonment of fifteen

\footnotetext{
${ }^{1}$ Tentara Nasional Indonesia Angkatan Darat. (2013). Ketentuan Petunjuk Induk Pendidikan TNI.

${ }^{2}$ Letjen TNI JS.Prabowo. (2011). Loyalitas dalam kehidupan keprajuritan. Yogyakarta. Percetakan kanisius. p.14
} 
years

Article 108 contains:

1) Insubordination by real action carried out by two or more persons unitedly, is threatened because of real resistance together with a maximum imprisonment of twelve years.

2) the act is threatened:

First, with a maximum imprisonment of fifteen years if because of the criminal acts he has committed or because of a real action related to the criminal act committed, resulting in injury;

Second, by a maximum temporary imprisonment of twenty years if the cause of death.

Article 109 contains:

By death penalty, life imprisonment or temporary imprisonment for a maximum of twenty years,

Insubordination by real action during war;

In relation to the formulation of the norms of the articles above, in detail the tabulation can be seen in table 1.

This is a reminder that the sanctions imposed on TNI soldiers who violate the provisions of Articles 106, 107, 108 and 109 of the Military Criminal Code are not automatically punished with the penalties stated in that article but are also subject to Military Discipline punishment as referred to in the Law Law No.26 of 1997 which can affect the career development of TNI soldiers, so that every TNI soldier who commits a military crime is automatically deemed to have committed a violation of military discipline.

Table. 1 Formulation of norms and sanctions for insubordination in the Criminal Code

\begin{tabular}{|c|c|c|c|c|c|c|c|c|}
\hline \multicolumn{9}{|c|}{ ELEMENTS OF CRIMINAL ACTS } \\
\hline \multirow[t]{2}{*}{ No. } & \multirow[t]{2}{*}{ Article } & \multirow{2}{*}{$\begin{array}{c}\text { The } \\
\text { subject of } \\
\text { a criminal } \\
\text { act }\end{array}$} & \multicolumn{2}{|c|}{$\begin{array}{l}\text { Subjective elements } \\
\text { Forms of error }\end{array}$} & \multirow[t]{2}{*}{$\begin{array}{l}\text { Objective elements of actions } \\
\text { prohibited by law }\end{array}$} & \multicolumn{3}{|c|}{ Punishment } \\
\hline & & & Purposely & negligent & & Criminal & Discipline & administration \\
\hline \multirow[t]{3}{*}{1} & $\begin{array}{l}106 \\
(1)\end{array}$ & Military & Purposely & - & $\begin{array}{l}\text { By taking real action, } \\
\text { attacking a commander, } \\
\text { fighting him with force or } \\
\text { threatening violence to carry } \\
\text { out or neglect an official job, } \\
\text { threatened because of } \\
\text { insubordination with real } \\
\text { action }\end{array}$ & $\begin{array}{l}\text { The maximum prison } \\
\text { term is } 9 \text { years }\end{array}$ & $\begin{array}{l}\text { - Warning } \\
\text { - Light } \\
\text { prisoner } \\
\text { - Heavy } \\
\text { resistance }\end{array}$ & $\begin{array}{l}\text { - Postponed } \\
\text { education } \\
\text { - Postponed } \\
\text { promotion } \\
\text { - Suspension } \\
\text { - Fired }\end{array}$ \\
\hline & (2) & Military & Purposely & negligent & Resulted in wounds & $\begin{array}{l}\text { The maximum prison } \\
\text { term is } 10 \text { years }\end{array}$ & Idem & Idem \\
\hline & (3) & Military & Purposely & negligent & Resulted in death & $\begin{array}{l}\text { The maximum prison } \\
\text { term is } 12 \text { years }\end{array}$ & Idem & Idem \\
\hline \multirow[t]{3}{*}{2} & $\begin{array}{l}107 \\
(1)\end{array}$ & Military & Purposely & - & $\begin{array}{l}\text { Insubordination with concrete } \\
\text { actions planned in advance }\end{array}$ & $\begin{array}{l}\text { The maximum prison } \\
\text { term is } 10 \text { years }\end{array}$ & Idem & Idem \\
\hline & (2) & Military & Purposely & negligent & Resulted in wounds & $\begin{array}{l}\text { The maximum prison } \\
\text { term is } 12 \text { years }\end{array}$ & Idem & Idem \\
\hline & (3) & Military & Purposely & negligent & Resulted in death & $\begin{array}{l}\text { The maximum prison } \\
\text { term is } 15 \text { years }\end{array}$ & Idem & Idem \\
\hline \multirow[t]{3}{*}{3} & $\begin{array}{l}108 \\
(1)\end{array}$ & Military & Purposely & negligent & $\begin{array}{l}\text { Insubordination with concrete } \\
\text { actions taken by two or more } \\
\text { people unitedly }\end{array}$ & $\begin{array}{l}\text { The maximum prison } \\
\text { term is } 12 \text { years }\end{array}$ & Idem & Idem \\
\hline & $\begin{array}{l}(2) \\
\text { No. } 1\end{array}$ & Military & Purposely & negligent & Resulted in wounds & $\begin{array}{l}\text { The maximum prison } \\
\text { term is } 15 \text { years }\end{array}$ & Idem & Idem \\
\hline & No. 2 & Military & Purposely & negligent & Resulted in death & $\begin{array}{l}\text { The maximum temporary } \\
\text { prison term is } 20 \text { years in } \\
\text { prison }\end{array}$ & Idem & Idem \\
\hline \multirow[t]{2}{*}{4} & $\begin{array}{c}109 \\
\text { No. } 1\end{array}$ & Military & Purposely & negligent & $\begin{array}{l}\text { Insubordination with real } \\
\text { action in time of war }\end{array}$ & $\begin{array}{l}\text { Life or temporary } \\
\text { imprisonment for a } \\
\text { maximum of } 20 \text { years }\end{array}$ & Idem & Idem \\
\hline & No. 2 & Military & Purposely & negligent & $\begin{array}{l}\text { Real joint resistance on a boat } \\
\text { or plane in a place where } \\
\text { there is no help }\end{array}$ & $\begin{array}{l}\text { Life or temporary } \\
\text { imprisonment for a } \\
\text { maximum of } 20 \text { years }\end{array}$ & Idem & Idem \\
\hline
\end{tabular}

Source: Primary Legal Materials (processed)

The imposition of military discipline sanctions is an absolute matter in the military body for TNI soldiers who violate the law because they are considered representatives of Sapta Marga and the soldier's oath.

Meanwhile, in the article on Insubordination, there is a criminal act subject who is none other than military with a subjective element, namely the mistake which has been formulated as an intent. Likewise the objective element, namely actions or actions that are not justified by law, which constitute insubordination. In this case, insubordination fulfills the element if the TNI perpetrators or soldiers take a fight against their superiors in circumstances that are tied to official duties, namely not carrying out or ignoring orders from their superiors. The commander referred to in this article does not explicitly describe what is meant by a direct commander or not a direct commander. Meanwhile in various military provisions the right to govern subordinates is the direct commander as outlined in the general provisions of Law No. 25 of 2014 . However, the commander's orders must 
be obeyed without the need to classify whether the commander is direct commander or not the direct commander. This has become a common practice, that in military life there is a hierarchy of loyalty which is often referred to as a "rank" of seniority or a priority scale gradually starting from loyalty to the Unitary State of the Republic of Indonesia (NKRI), the government, the TNI in succession to the commander. directly down to fellow soldiers and units.

Then the next thing that becomes a concern is the element of deliberately attacking the commander, which is certainly a subjective attitude of the perpetrator's inner self which is also influenced by external factors, so that TNI soldiers who commit crimes of insubordination are not only threatened with imprisonment, but are also threatened with military discipline as stipulated in Article 8 Law No.25 of 2014 which categorizes the types of violations of military discipline, consisting of:

a. All actions that are contrary to official orders, official regulations or actions that are not in accordance with Military Regulations, and

b. Acts that violate criminal laws and regulations are of such a mild nature.

So it can be made clear that no matter how light the violations were committed by TNI soldiers, the military law will still be subject to disciplinary sanctions with the threat of punishment in the form of reprimands, light detention of a maximum of 14 days, and severe detention of 21 days. The imposition of disciplinary sanctions is also followed by the threat of administrative punishment as in Article 9 of Law No.25 of 2014.

\section{The Purpose of Law Enforcement of The Crime of Insubordination}

The understanding of the military as a military law subject to the provisions of the criminal act of insubordination is of course an absolute matter, not only because of compulsion but also must be embedded in the heart of TNI soldiers so that they are able to become representatives of the implementation of the oath of soldiers and sapta marga. If tracing the nature of the insubordination arrangements in the Military Criminal Code, the following will be found:

\section{1) Protect The Commander's Honor}

The concept of insubordination originates from the attitude of the subordinates in maintaining the spirit of the commander so that it does not cause harm to the commander as well as the dignity that must be upheld by the subordinates. The treatment of subordinates is arranged in such a way towards the commander to maintain synergy within the unit. Whenever something happens that reduces the spirit of the commander by resisting or disobeying it, it can be ascertained that the duties and responsibilities in the area of the unit cannot run properly. Chaos will arise as a result of miscommunication, the jurisdiction in his unit will become irregular and disturb the stability of security. The commander has the power and authority in regulating matters that are the responsibility of the unit so that insubordination is not justified because the commander's instructions are so important to subordinates in carrying out military duties. When insubordination occurs, it is clear that subordinates have indirectly tarnished their good name because they have the potential to be given legal sanctions and also accompanying disciplinary sanctions. ${ }^{1}$

The development of insubordination patterns becomes interesting when the commander becomes a subject who must also understand the psychological condition of his subordinates. The psychological condition of subordinates is something that cannot be justified. As in criminology, there are factors that influence the occurrence of a crime. These factors can be external as well as internal. The tendency of subordinates to make threats and even violence against the commander cannot continue to be allowed to become a culture to solve problems. The Republic of Indonesia as a pillar of the country requires solidarity as the intent of the unit of command in carrying out its duties and responsibilities.

Therefore, to maintain the commander's spirit, of course a commander must understand the value of an order. The value of an important order is understood as expressed by TNI General Endriartono Sutarto ${ }^{2}$ that the wrong order is obligatory not to be implemented. This controversial statement is quite surprising considering the commander's order is the prerogative of subordinates. However, in maintaining the commander's spirit, this statement later became one of the rules in the task relationship between subordinates and the commander. There is a right for subordinates to judge the quality of an order so that it can be thought material to carry out or not carry out an order based on their assessment. Because more or less a soldier has the wisdom to judge the quality of an order, whether the order is correct or not, whether the order violates statutory regulations or not because he has had provisions during training to become a TNI soldier.

This is also the basis for the birth of Article 18 of Law No.25 of 2014 which states that in carrying out orders, subordinates are obliged to:

a. Understand the purpose and content of the order given, if it is not clear, it is obligatory to ask the

\footnotetext{
${ }^{1}$ Interview with the Junior Military Registrar at the Supreme Court.

${ }^{2}$ Letjen TNI JS.Prabowo. (2011). Loyalitas dalam kehidupan keprajuritan. Yogyakarta: Percetakan kanisius. p.23.
} 
Commander who gave the order;

b. Repeating the contents of the order or conveying an understanding of the purpose of the order to the Commander who gave the order;

c. Submit a report to the Commander who gives orders on the implementation and the results achieved from the order;

d. Responsible to the Commander who gives orders for the execution of orders;

Understanding commanders and subordinates of the value of an order will create a conducive atmosphere. Commanders who can be trusted by subordinates because they have good integrity which will indirectly increase the loyalty of subordinates. Because true loyalty is not just obedient and loyal which can be seen from the outside but a character that is owned or embedded in the soul of a soldier. So it can be concluded that the commander's spirit will be maintained when a commander knows and understands his capacity as a leader and avoids arbitrariness against subordinates.

\section{2) Subordinate Obedience}

Military soldiers are citizens who are elected as someone with good or even best honors, this is undeniable considering the duties and responsibilities that are on their shoulders as a bulwark. Nothing wrong with then if TNI soldiers have characteristics that are not shared by other people in general. These characteristics, namely ${ }^{1}$ :

a. Knights in defending and maintaining state security and guaranteeing from any attacks based on Pancasila;

b. Patriotic, self-sacrificing and never giving up on the tasks assigned to the nation and nation;

c. Steadfast in carrying out his obligations in his duties so as not to become a coward who runs away from his service;

d. Upholding warrior attitude, prioritizing heroism in carrying out duties and obeying the commander / leadership;

e. Mastering day-to-day duties and obligations and helping prevent a prohibited act;

f. Simple in appearance, never lying and stealing;

g. Good at maintaining state assets, especially those entrusted to him;

The nature and actions that contradict the above description are certainly not expected of a TNI soldier.

In point (d) above, it has been detailed how the subordinates are ready to be alert to the commander's orders in another sense, they must obey so that if they conflict with these characteristics, it will certainly be a boomerang for TNI soldiers / subordinates because it is an insubordination.

Obedience to the commander is an embodiment of military life related to the spirit of Corsa and solidarity. The obedient attitude which is Indonesian culture is manifested in the military rule between commanders and subordinates. Regardless of age, if the rank was higher than the subordinate who was older than the commander, then there was no reason to disobey the commander. Likewise with kinship relations, no matter which Uncle is in a lower rank than the nephew of a higher rank, there is also no reason to disobey the commander's orders. The Korsa soul that is inherent in the military body is the main force to maintain stability in the military body and to fight soldier egoism ${ }^{2}$.

The commander referred to as stipulated in Article 13 of Law No.25 of 2014, namely:

1. The commander consists of:

a. Military in a higher position, and

b. Military positions higher.

The next article explains that if the ranks are the same, then the position is reviewed from the length of time said rank is held. Then if the rank and length of time being carried are the same, then the position is seen from the length of time in office. If the length of time serving as a jabawan is also the same, then the position is seen from the length of time he has been in the military and the last if the length of time in the military remains the same, the position as commander is seen from his age.

This was also stated by the First Admiral of the TNI Sinoeng Harjanti ${ }^{3}$ That the hierarchy between commanders and subordinates is as follows:

a. Position indicators,

b. The length of time the position has been acquired,

c. Structural positions, and

d. Age

This hierarchy of ranks serves as a guideline for both commanders and subordinates in acting so that there is no friction between them. In addition, this hierarchy also shows the extent to which responsibility is assumed. The higher the rank and position of the commander, of course, will coincide with the responsibilities assigned to the

\footnotetext{
1 S.R Sianturi. (2010). Hukum Pidana Militer di Indonesia, Jakarta: Babinkum TNI. p.166

2 Interview with the Junior Military Registrar at the Supreme Court

3 Interview with Deputy head of the Main Military Court
} 
unit. This is also a factor in the commander's assertiveness to his subordinates. However, commanders who do not get sympathy from their subordinates will affect aspects of life in the territory of their unit. It is important for commanders to become pioneers who are used as role models for their subordinates so that without coercion, subordinates will have attitudes and behaviors that show loyalty to the unity, nation and state.

Subordinates must maintain their obedient attitude towards their commander because it can damage the military's joints if the subordinates' attitude changes to become dissidents and against the commander. Obedience is a form of behavioral expression, whereas obedience is a form of action by subordinates in carrying out the command of the commander.

As stated in Article 18 of the TNI Commander's Decree, it is stated that every subordinate or soldier of the TNI must obey, respect or submit to his commander by upholding all orders and service directives expressed by the commander truthfully and consciously that regarding the commander's order to To maintain the spirit and interests of the service, a soldier should obey, respect or submit to his commander not only within the service but also outside the service in order to uphold the honor inherent in the soldier, besides that a soldier should maintain their ethics or attitude both inside and outside the service. So that in maintaining the spirit of the commander and the obedience of subordinates, it becomes 2 (two) very important things as a basis for preventing the occurrence of insubordination crimes. For this reason, in order to avoid the crime of insubordination, the discipline of soldiers must be adhered to firmly by referring to the command principle.

The discipline of military soldiers as an indicator for the character building of TNI soldiers has become so urgent that Law No. 25 of 2014 was formed. Before this law came into effect, Law No. 26 of 1997 first took effect after replacing the Military Discipline Code. Changes in military discipline enforcement instruments show the development of patterns and behavior of military life. The goal to be achieved is of course in order to keep pace with the times and not to harm the sapta marga and the soldier's oath.

\section{Conclusion}

The legal arrangements for insubordination crime committed by the military are regulated in the Military Criminal Code and are also based on Military Discipline penalties which refer to Law No. 25 of 2014, this arrangement becomes a legal basis when the military commits a crime of insubordination so that the military can carry out their duties with a full sense of responsibility and adhere to the commander and the applicable law.

\section{References}

Achmad Ali, (2002), Menguak Tabir Hukum (Suatu Kajian Filosofis dan Sosiologis), Jakarta : Tokoh Gunung Agung.

Akub, M. S., \& Ilyas, A. (2013). Wawasan Due Process Of Law Dalam Sistem Peradilan Pidana. Rangkang Education.

Amu, Robi. (2012). Kajian Hukum Pidana Militer Indonesia Terhadap Tindak Pidana Desersi. Jurnal Legalitas, Vol 5.01.

Andi Muhammad Sofyan, \& Asis, A. (2014). Hukum Acara Pidana Suatu Pengantar. Jakarta: Kencana.

Azikin, Arqam, and Marwati Riza. (2020). Legal Policy of National Defense: Developing National Character in Indonesia. JL Pol'y \& Globalization Vol. 97.

Bukhari, A., \& Abudan, M. (2019). Penegakan Hukum Tindak Pidana Insubordinasi Dalam Militer (Studi Kasus Putusan Pm Nomor: 94-K/Pm. Iii-12/Ad/Vi/2015). Jurnal Hukum Adigama, 2(1), 74-97.

Cahyadi, Cokorda Bagus Aries. (2017). Kajian Hukum Militer Terhadap Tni Yang Melakukan Tindak Pidana Desersi. Jurnal Kertha Wicaksana, Vol. 1.3.

Chandra, R. (2020). Penyelesaian Kasus Hukum Di Lingkungan Pengadilan Militer Dalam Perkara Tindak Pidana Penipuan Yang Dilakukan Oleh Anggota Tni. Pamulang Law Review, 1(2), 75-86.

Efendy, Rifki. (2014). Kedudukan dan kewenangan Tentara Nasional Indonesia dalam pemberantasan terorisme di indonesia. Lex Crimen, Vol 3.1.

Haris, O. K., \& Hidayat, S. (2019). Pertanggungjawaban Pidana Anggota Militer Yang Melakukan Tindak Pidana Insubordinasi Dengan Tindakan Nyata Dalam Peradilan Militer. Halu Oleo Legal Research, 1(1), 99-110.

Hendrik, Jhoni. (2019). Penanggulangan Tindak Pidana Desersi Terhadap Prajurit Tni Al. Unes Journal Of Swara Justisia, Vol. 3.1: 78-91.

Kesumo, E. (2011). Proses Peradilan Terhadap Prajurit Tni Yang Melakukan Tindak Pidana Umum. Doctoral Dissertation, Universitas Airlangga.

Letjen TNI JS. Prabowo. (2011). Loyalitas dalam kehidupan keprajuritan. Yogyakarta. Percetakan Kanisius.

Putra, Ivandra Oktarino. (2019). Pertimbangan Mahkamah Agung Mengabulkan Permohonan Kasasi Oditur Militer Terhadap Putusan Bebas Dalam Perkara Tindak Pidana Pencurian dalam Keadaan Memberatkan. Verstek, Vol.7.1.

Putra, T. D. (2013). Penerapan Hukum Militer Terhadap Anggota TNI Yang Melakukan Tindak Pidana Desersi. Lex Crimen, 2(2). 
Prajurit Tni Pelaku Tindak Pidana Umum. Law Reform, 7(1), 21-49.

Randy, Yavisparta, and Mahendra Putra. (2015). Asas Unus Testis Nullus Testis Sebagai Dasar Terdakwa Mengajukan Permohonan Banding Ke Pengadilan Militer Utama." Verstek, Vol.3.2.

Rudiansyah, Rudiansyah. (2018). Tinjauan Yuridis Terhadap Pelanggaran Prajurit Militer Di Lingkunagn Korem 101 Antasari Banjarmasin Menurut Undangundang Nomor 25 Tahun 2014 Tentang Hukum Disiplin Militer. Repository Universitas Islam Kalimantan..

Sa'diyah, Nur Khalimatus, and Ria Tri Vinata. (2016). Rekonstruksi Pembentukan National Cyber Defense sebagai Upaya Mempertahankan Kedaulatan Negara. Perspektif: Kajian Masalah Hukum dan Pembangunan, Vol. 21.3: 168-187.

Sainuddin, L. Magassing, A. M. Sakhrina, I.K. Bakhtiar, H.S. (2017). Legal Analysis of Crime Terrorism and Counter Terrorism Strategy. International Journal of Advanced Research (IJAR), 5(7), 93.

Sinaga, N. S. Pembangkangan Militer (Melanggar Pasal 103 Kuhpm) Di Lingkungan Tni AD Di Wilayah Yonif 643/Wanara Sakti Kompi B Ditinjau Dari Sudut Kriminologi. Jurnal Hukum Prodi Ilmu Hukum Fakultas Hukum Universitas Tanjungpura, 3(3).

Sirait, B., \& Sahari, A. (2014). Peranan Polisi Militer Angkatan Udara Di Dalam Penyidikan Kasus Narkoba Dalam Wilayah Hukum Lanud Soewondo (Medan). Jurnal Mercatoria, 7(1), 30-45.

Soebagijo, H. (2011). Kebijakan Hukum Pidana Dalam Pemeriksaan Terhadap Tommy Sihotang, (2009). Penelaahan Hukum Militer untuk Memperkuat Ketahanan Nasional dan Perlindungan Hak Asasi Manusia, Sekretariat Jenderal Departemen Pertahanan Biro Hukum.

Soerjono Soekanto, (1986), Pengantar Penelitian Hukum, Jakarta: UI Press.

S.R Sianturi. (2010). Hukum Pidana Militer di Indonesia, Jakarta: Babinkum TNI.

Tiku, I. A. (2020). Kajian Yuridis Terhadap Tindak Pidana Korupsi Yang Di Lakukan Oleh Pejabat Tni. Lex Crimen, 9(2).

Tentara Nasional Indonesia Angkatan Darat. (2013). Ketentuan Petunjuk Induk Pendidikan TNI. 